\title{
Loss of hippocampal $\left[{ }^{3} \mathrm{H}\right] \mathrm{TCP}$ binding in Alzheimer's disease
}

\author{
William F. Maragos ${ }^{3}$, Dorothy C.M. Chu ${ }^{3}$, Anne B. Young ${ }^{1}$, \\ Constance J. D'Amato ${ }^{2}$ and John B. Penney Jr.' \\ Deparments of 'Neurology' and 'Pathology and 'the Neuroscience Program, University of Michigan. Ann \\ Arbor, M/ 48104 (U.S.A.)
}

(Received 25 July 1986: Revised version received and accepted 15 October 1986)

Key words: ['H]N-(1-[2-thienyl]cyclohexyl)3,4-piperidine (['H]TCP); Alzheimer's disease: Receptor: $\mathrm{CA}_{1}$ : Subiculum; $N$-methyl-1)-aspartate (NMDA); Man

\begin{abstract}
We have previously demonstrated a marked loss in $N$-methyl-D-aspartate (NMDA) receptors in the hippocampus and cerebral cortex of patients dying with dementia of the Alzheimer type (DAT). In addition. we have found that the dissociative anesthetic $N$-(1-[2-thienyl]cyclohexyl)3,4-piperidine (['H]TCP) binds to a site whose regional distribution is highly correlated with that of NMDA receptor sites. We studied the binding of ['H]TCP to sections of hippocampi from 8 controls, 12 patients with DAT and 7 patients with other dementias. ['H]TCP binding was significantly reduced in strata pyramidalia of $\mathrm{CA}_{1}: \mathrm{CA}_{2}, \mathrm{CA}_{3}$ and subiculum of DAT hippocampal formation compared to that of control. Labelled dissociative anesthetics could potentially be used with positron emission tomography in the diagnosis of DAT.
\end{abstract}

Tritiated $N$-(1-[2-thienyl]cyclohexyl)3,4-piperidine $\left(\left[{ }^{3} \mathrm{H}\right] \mathrm{TCP}\right)$ is a derivative of the dissociative anesthetic phencyclidine. $\left[{ }^{3} \mathrm{H}\right] \mathrm{TCP}$ has recently been shown to bind with high affinity to a distinct class of central nervous system binding sites which are most concentrated in the hippocampus and outer regions of cerebral cortex [20]. The pharmacology of $\left[{ }^{3} \mathrm{H}\right] \mathrm{TCP}$ binding is most consistent with binding to the dissociative anesthetic site (PCP-site) [27] and not to the $\sigma$-opiate receptor [13]. Recent electrophysiological data suggest that the dissociative anesthetics block the excitatory action of $N$-methyl-D-aspartate (NMDA) on hippocampal [5] and spinal cord neurons [16]. as well as on pyramidal cells in rat somatosensory cortex [24]. Behavioral data also support an interaction between the dissociative anesthetic receptor and the NMDAsensitive glutamate receptor. The dissociative anesthetics produce similar behavioral changes to those induced by NMDA antagonists [12]. Moreover, we have recently shown that the regional distribution of $\left[{ }^{3} \mathrm{H}\right] \mathrm{TCP}$ binding in rat forebrain is highly correlated with the regional distribution of $\left[{ }^{3} \mathrm{H}\right]$ glutamate binding to NMDA receptors [15].

Correspondence: J.B. Penney Jr., The University of Michigan, Neuroscience Laboratory Building, 1103 East Huron Street, Ann Arbor, MI 48104, U.S.A. 
$\left[{ }^{3} \mathrm{H}\right]$ Glutamate binding to brain sections obtained from patients dying with dementia of the Alzheimer type (DAT) has been shown to be markedly reduced in cerebral cortex [9] and hippocampus [8]. Although all subtypes of glutamate receptors are itfected in DAT, the most pronounced changes are in the NMDA subtype. We now report our studies of $\left[{ }^{3} \mathrm{H}\right] \mathrm{TCP}$ binding to Alzheimer brain.

Postmortem brains from 6 persons dying without neurologic disease, 3 persons $\mathrm{dy}$ ing with other forms of dementia (two Huntington's disease and one case of diffuse cortical atrophy without DAT pathology) and 4 persons dying with dementia of the Alzheimer type were obtained through our Department of Pathology. After autopsy. one hemisphere of each brain was fixed in formalin and the other hemisphere was blocked, frozen over dry ice and sealed in containers at $-70^{\circ} \mathrm{C}$ until examination. Diagnosis of DAT was histologically verified in fixed sections according to the criteria outlined by Khachaturian [11]. Blocks of hippocampus (approximately $5 \mathrm{~mm}$ ) were removed from each frozen hemisphere at the level of the lateral geniculate and equilibrated in a cyrostat at $-15^{\circ} \mathrm{C}$ for $0.5 \mathrm{~h}$. Sections of $20 \mu \mathrm{m}$ were then thawmounted onto gelatin/chrom-alum coated glass slides. Sections were preincubated for $30 \mathrm{~min}$ in cold $50 \mathrm{mM}$ Tris-acetate, $\mathrm{pH} 7.4$ and dried. Sections were incubated for $45 \mathrm{~min}$ in the same buffer with $1 \mathrm{mM}$ magnesium acetate and $20 \mathrm{nM}\left[{ }^{3} \mathrm{H}\right] \mathrm{TCP}$ $(52.9 \mathrm{Ci} / \mathrm{mmol}$, New England Nuclear) in the presence or absence of $20 \mu \mathrm{M} \mathrm{PCP}$ at $4^{\circ} \mathrm{C}$. Sections were washed 3 times, 1 min each, in cold buffer with magnesium acetate and rapidly dried. Slides were subsequently mounted in stainless-steel X-ray cassettes and apposed to a piece of Ultrofilm ${ }^{3} \mathrm{H}$ (LKB). After 3 weeks exposure, the films were developed in D-19 (Kodak). Autoradiograms were analyzed by computer-assisted densitometry according to the method of Pan et al. [18]. The amount of $\left[{ }^{3} \mathrm{H}\right] \mathrm{TCP}$ bound, in $\mathrm{pmol} / \mathrm{mg}$ protein, was determined by comparing the optical densities produced by the labelled tissue with densities produced by plastic standards containing known amounts of radioactivity [18]. Sections underlying the autoradiograms were stained with Cresyl violet to provide histological verification of hippocampus and subiculum as defined by Lorente de Nó [14]. A minimum of 20 readings were taken from each of several different areas on each section to determine total binding. Nonspecific binding was determined similarly from adjacent sections. Specific binding was obtained by subtracting non-specific from total binding. The assays and all the densitometric readings were carried out by an experimenter blind to the patients' diagnoses.

In control hippocampi binding was highest in the strata pyramidalia of $\mathrm{CA}_{1} / \mathrm{CA}_{2}$ $\left(\mathrm{CA}_{1}\right)$ and the subiculum (SUB) (Figs. 1 and 2). High densities were also observed in the molecular layer of the dentate gyrus (DG). Binding was intermediate in stratum moleculare of $\mathrm{CA}_{1}\left(\mathrm{SMCA}_{1}\right)$, outer layers of adjacent parahippocampal isocortex (PAR), stratum pyramidale of $\mathrm{CA}_{3}\left(\mathrm{CA}_{3}\right)$ and quite low in pre- and parasubiculum. Because caudal levels of hippocampus were examined, little to no entorhinal cortex was present for examination.

$\left[{ }^{3} \mathrm{H}\right] \mathrm{TCP}$ binding in brains from patients with non-DAT dementia were indistinguishable from those of controls (Fig. 2). However, $\left[{ }^{3} \mathrm{H}\right] \mathrm{TCP}$ binding to DAT hippocampus appeared decreased relative to the other groups in all areas inspected 


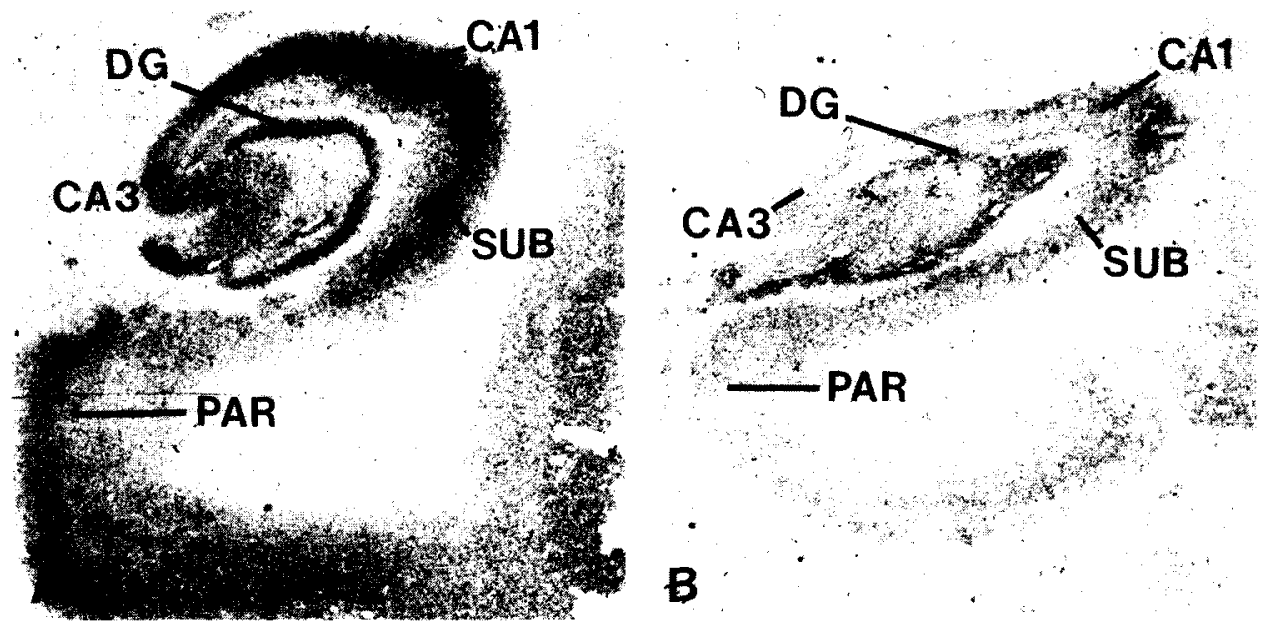

Fig. 1. Autoradiograms of [ $\left.{ }^{3} \mathrm{H}\right]$ TCP binding in human hippocampus. Tissue was incubated in $20 \mathrm{nM}$ $\left[{ }^{3} \mathrm{H}\right] \mathrm{TCP}$ for $45 \mathrm{~min}$ and processed for autoradiography as described in text. A: normal control. B: $\mathrm{Al}$. heimer's disease. $\mathrm{CA}_{1}$, stratum pyramidale of $\mathrm{CA}_{1} / \mathrm{CA}_{2} ; \mathrm{CA}_{3}$, stratum pyramidale of $\mathrm{CA}_{3}$ : $\mathrm{DG}$, molecular layer of dentate gyrus: PAR, parahippocampal cortex: SUB, subiculum.

except the molecular layer of the dentate gyrus and pre- and parasubiculum (Figs. 1 and 2). Reductions in binding relative to control were $55 \%$ in $\mathrm{CA}_{1}\left(F_{2,10}=3.67\right.$; not significant (n.s.), $40 \%$ in $\operatorname{SUB}\left(F_{2,9}=2.85 ;\right.$ n.s. $), 40 \%$ in $\operatorname{SMCA}_{1}\left(F_{2.7}=1.80 ;\right.$ n.s. $), 30 \%$

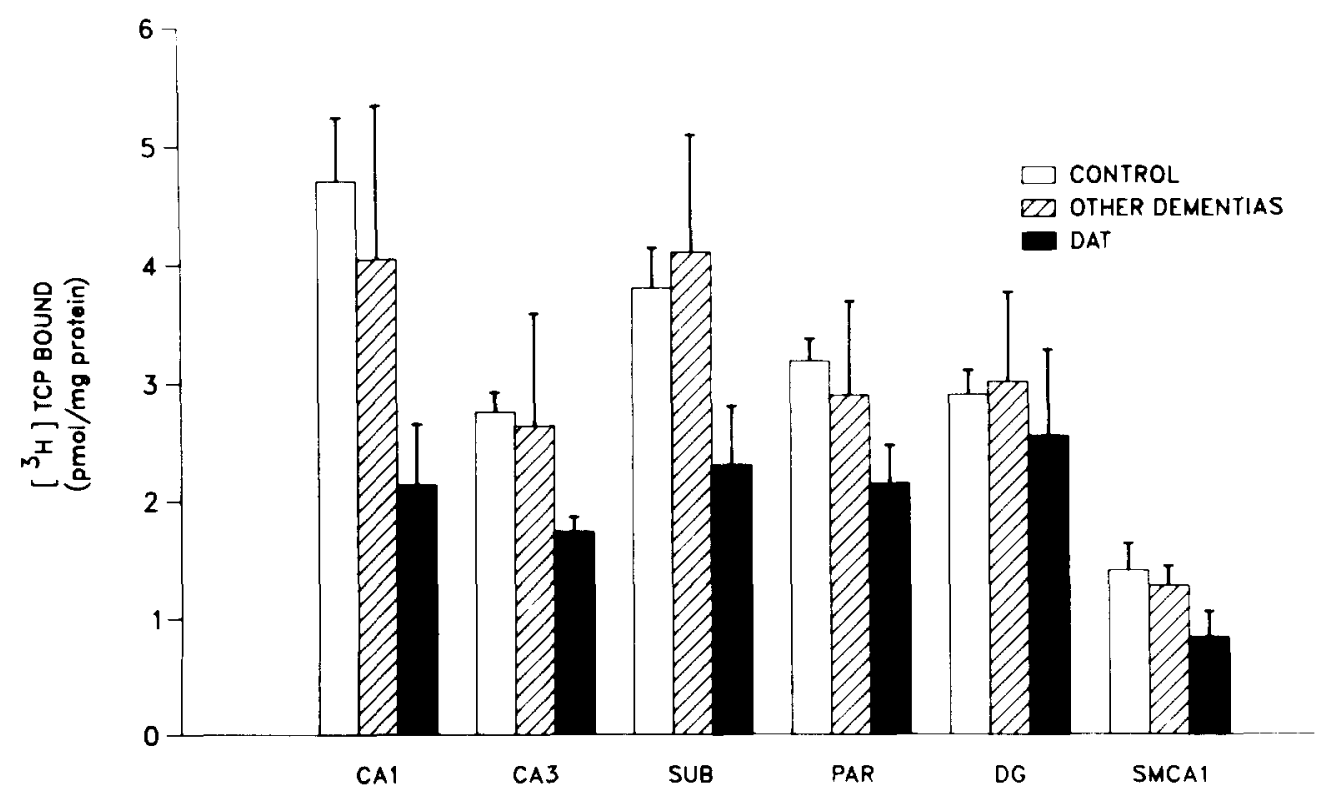

Fig. 2. Histogram of binding to hippocampal subregions of 6 control patients, 3 demented patients without Alzheimer's disease (other dementia) and 4 DAT patients. Error bars represent S.E.M. Abbreviations are as in text. 
in $\mathrm{CA}_{3}\left(F_{2,7}=2.01\right.$; n.s. $)$ and $33 \%$ in $\operatorname{PAR}\left(F_{2,8}=2.98\right.$; n.s. $)$ using one way ANOVA.

In order to increase our sample, an additional 14 hippocampi ( 2 controls, 4 other dementia ( 3 diffuse atrophy, 1 Pick's disease) and 8 DAT cases) were analyzed blindly and in a fashion identical to that described above except that $40 \mathrm{nM}\left[{ }^{3} \mathrm{H}\right] \mathrm{TCP}$ was used instead of $20 \mathrm{nM}\left[{ }^{3} \mathrm{H}\right] \mathrm{TCP}$. As expected, assays carried out in the presence of increased concentrations of $\left[{ }^{3} \mathrm{H}\right] \mathrm{TCP}$ significantly increased the amount of binding to all areas (data not shown). When the results from the two experiments were pooled and compared by two-way ANOVA using the BMDP statistical software package (Regents of the University of California), decreased binding to DAT brains was observed in $\mathrm{CA}_{1}\left(F_{2,20}=4.94 ; P=0.02\right), \mathrm{CA}_{3}\left(F_{2,13}=4.19 ; P=0.04\right)$ and probably in the SUB $\left(F_{2,18}=3.27 ; P=0.06\right)$. Since there were no differences in the amount of $\left[{ }^{3} \mathrm{H}\right]$ TCP binding in control and non-DAT dementia cases in both experiments, results from these two groups were combined and compared to DAT by two-way ANOVA. Significant decreases were found in $\mathrm{CA}_{1}\left(F_{1,22}=9.27 ; P=0.006\right)$, SUB $\left(F_{1,20}=7.22 ; P=0.014\right)$ and $\mathrm{CA}_{3}\left(F_{1,15}=6.41 ; P=0.02\right)$.

For the two experiments average postmortem delay was $22 \pm 6 \mathrm{~h}$ for the controls, $14 \pm 2 \mathrm{~h}$ for the non-Alzheimer's demented cases and $14 \pm 3 \mathrm{~h}$ for patients dying with $\operatorname{DAT}\left(F_{2.21}=0.895\right.$; n.s. $)$. Average age of the patients was $60 \pm 6$ for the controls. $62 \pm 5$ for the non-Alzheimer's cases and $74 \pm 3$ for the DAT cases $\left(F_{2,24}=3.18 ;\right.$ n.s. $)$. Multiple regression analysis revealed no significant relationship of age or postmortem delay with $\left[{ }^{3} \mathrm{H}\right] \mathrm{TCP}$ binding to any of the measured regions. One control patient was taking a calcium channel blocker, two DAT cases were taking low doses of haloperidol, two DAT cases were taking benzodiazepines, one DAT case and two nonDAT dementia cases were taking phenytoin and one non-DAT case was taking antiparkinsonian medication. The control cases had sudden cardiac or traumatic deaths. The DAT and non-DAT cases died of prolonged illnesses and several in both categories required artificial respiration for several days prior to death.

The hippocampus is a major site of pathology in DAT. In DAT brain, the hippocampus contains the greatest numbers of neurofibrillary tangles [1] and senile plaques [4] and has significant neurochemical changes including cholinergic [3], monoaminergic [2] and glutamatergic deficits [6, 8]. Functionally, the hippocampus has been associated with learning and memory. Bilateral lesions to this region produce severe memory deficits [19] as well as impairments on spatial learning tasks [23]. Anatomically, the hippocampus, via the parahippocampal gyrus, reciprocally connects the limbic cortex with a number of neocortical regions [26]. Loss of these connections due to the observed structural and chemical abnormalities may thus underlie the cognitive and memory deficits so prominent in DAT.

The areas of hippocampus which have the largest changes in dissociative anesthetic binding $\left(\mathrm{CA}_{1}\right.$ and $\left.\mathrm{SUB}\right)$ are those which contain significant anatomical pathology in DAT [10]. These areas are known to receive glutamatergic input $[21,28]$ and contain high densities of NMDA-sensitive receptors [7]. Furthermore, it is these regions in which the greatest losses of NMDA receptors in DAT were observed [8]. The CA 3 and molecular layers have less neuroanatomical pathology in DAT and, in this study, had lesser changes in dissociative anesthetic binding. The $\mathrm{CA}_{3}$ neurons receive input 
from the dentate granule cells [22] but much of the granule cells' actions are thought to be mediated by glutamate receptors sensitive to kainic acid [25]. The dentate gyrus is known to contain a large number of NMDA binding sites $[7,17]$ yet is relatively spared of plaques and tangles. Since we observed no changes in $\left[{ }^{3} \mathrm{H}\right] \mathrm{TCP}$ binding in this region it is possible that plaque and/or tangle formation may antedate reductions in the glutamate/PCP receptor complex.

The reductions in NMDA receptor binding in hippocampus [8] are more marked than the losses in dissociative anesthetic binding but the pattern of binding loss is similar for the two ligands. Whether TCP also binds to channels associated with other receptors is a possibility that needs further investigation. Nevertheless, the large decreases observed in $\left[{ }^{3} \mathrm{H}\right] \mathrm{TCP}$ binding might also be observed with a positronlabelled analog of TCP using positron emission tomography. Unlike glutamate and its analogs, the dissociative anesthetics enter brain rapidly and thus would be ideal potential ligands for in vivo imaging.

I Ball. M.J., Topographic distribution of neurofibrillary tangles and granulovacuolar degeneration in hippocampal cortex of aging and demented patients. A quantitative study, Acta Neuropathol., 42 (1978) 7380 .

2 Cross. A.J., Crow, T.J., Johnson, J.A., Joseph, M.H., Perry, E.K., Perry, R.H., Blessed, G. and Tomlinson. B.E.. Monoamine metabolism in senile dementia of Alzheimer type, J. Neurol. Sci., 60 (1983) 383392

3 Davies, P., Neurotransmitter-related enzymes in senile dementia of the Alzheimer type, Bratin Res.. $171(1979) 319327$.

4 Dayan, A.D., Quantitative histological studies on the aged human brain. II. Senile plaques and neurofibrillary tangles in senile dementia, Acta Neuropathol., 16 (1970) 95102.

5 Duchen, M.R., Burton, N.R. and Biscoe, T.J., An intracellular study of the interactions of $N$-methylDL-aspartate with ketamine in the mouse hippocampal slice, Brain Res., 342 (1985) 149-153.

6 Geddes, J.W., Monaghan, D.T., Cotman, C.W. Lott, I.T., Kim, R.C. and Chui. H.C. Plasticity of hippocampal circuitry in Alzheimer's disease, Science, 230(1985) 11791181.

7 Greenamyre. J.T., Olson, J.M.M., Penney, J.B. and Young, A.B., Autoradiographic characterization of $N$-methyl-1)-aspartate-, quisqualate-, and kainate-sensitive glutamate binding sites, J. Pharmacol. Exp. Ther., 233 (1985) 254 -263.

8 Greenamyre, J.T., Penney, J.B., D'Amato, C.J. and Young, A.B., Dementia of the Alzheimer's type: changes in hippocampal $1 .-[H]$ glutamate hinding. J. Neurochem., in press.

9 Greenamyre, J.T., Penney, J.B., Young, A.B., D'Amato. C.J., Hicks, S.P., and Shoulson, I., Alterations in 1.-glutamate binding in Alzheimer's and Huntington`s diseases, Science, 227 (1985) 1496. 1499 .

10 Hyman, B.T., Van Hoesen, G.W., Damasio, A.R. and Barnes, C.L.. Alzheimer's disease: cell-specific pathology isolates the hippocampal formation, Science, 225 (1984) 11681170.

11 Khachaturian, Z.S., Diagnosis of Alzheimer's disease, Arch. Neurol.. 42 (1985) 10971105.

12 Koek. W.. Kleer, E., Mudar, P.J. and Woods. J.H., Phencyclidine-like catalepsy induced by the excitatory amino acid antagonist DL-2-amino-5-phosphonovalerate, Bchav. Brain Res., 19 (1986) 257259.

13 Largent, B.L., Gundlach, A.L. and Snyder, S.H., Pharmacological and autoradiographic discrimination of sigma and phencyclidine receptor binding sites in brain with $(+)\left[{ }^{3} \mathrm{H}\right] \mathrm{SK} F \mathrm{~F} 10,047,(+)\left[{ }^{3} \mathrm{H}\right], 3-\mathrm{PPP}$ and [ ${ }^{3}$ H]TCP. J. Pharmacol. Exp. Ther., 238 (1986) $739-749$

14 Lorente de Nó. R., Studies on the structure of the cerebral cortex. II. Continuation of the study of the ammonic system. J. Psychol. Neurol.. 46 (1934) $113 \cdots 177$.

15 Maragos, W.F.. Chu, D.C.M., Greenamyre, J.T., Penney, J.B. and Young, A.B.. High correlation between the localization of $\left[{ }^{3} \mathrm{H}\right] \mathrm{TC}$ P binding and NMDA receptors, Eur. J. Pharmacol., 123 (1986) 173174 . 
16 Martin, D. and Lodge, D., Ketamine acts as a non-competitive $N$-methyl-D-aspartate antagonist on frog spinal cord in vitro, Neuropharmacology, 24 (1985) 999-1003.

17 Monaghan, D.T. and Cotman, C.W., Distribution of $N$-methyl-1-aspartate-sensitive L-[?H] glutamate hinding sites in rat brain, J. Neurosci., 3 (1985) 29092919.

18 Pan, H.S., Frey, K.A.. Young, A.B. and Penney, Jr., J.B., Changes in [ $\left.{ }^{3} \mathrm{H}\right]$ muscimol binding in substantia nigra, entopeduncular nucleus, globus pallidus, and thalamus after striatal lesions as demonstrated by quantitative receptor autoradiography, J. Neurosci.. 3 (1983) 1189-1198.

19 Scoville, W.B. and Milner, B., Loss of recent memory after bilateral hippocampal lesions, J. Neurol Neurosurg. Psychiat., 20 (1957) 1121.

20 Sircar, R. and Zukin, S.R., Quantitative localization of [ $\left.{ }^{3} \mathrm{H}\right] \mathrm{TCP}$ binding in rat brain by light microscopy autoradiography, Brain Res., 344 (1985) 142145.

21 Storm-Mathisen, J., Glutamic acid and excitatory nerve endings: reduction of glutamic acid uptake after axotomy, Brain Res., 120 (1977) $379-386$.

22 Swanson, L.W., Wyss, J.M. and Cowan, W.M., An autoradiographic study of the organization of intrahippocampal association pathways in the rat, J. Comp. Neurol., 181 (1978) 681716.

23 Thompson, R., Rapid forgetting of a spatial habit in rats with hippocampal lesions, Science, 212 (1981) 959960

24 Thomson. A.M., West, D.C. and Lodge, D., An $N$-methylaspartate receptor-mediated synapse in ra! cerebral cortex: a site of action of ketamine?, Nature (London), 313 (1985) 479481

25 Tremblay, E., Represa, A. and Ben-Ari, Y., Autoradiographic localization of kainic acid binding sites in the human hippocampus, Brain Res., 343 (1985) $378-382$.

26 Van Hoesen. G.W.. The parahippocampal gyrus: new observations regarding its cortical connections in the monkey, Trends Neurosci., 5 (1982) 345350

27 Vignon, J., Chicheportiche, R., Chicheportiche, M., Kamenka, J.-M., Geneste, P. and Lazdunski, M., ['H]TCP: a new tool with high affinity for the PCP receptor in rat brain, Brain Res., 280 (I983) 194 197.

28 White, W.F., Nadier, J.V., Hamberger, A., Cotman, C.W. and Cummins, J.T., Glutamate as a transmitter of the hippocampal perforant path, Nature (London), 270 (1977) 356 357. 